\title{
OVERCOMING RESISTANCE TO INNOVATION: SUGGESTIONS FOR ENCOURAGING CHANGE IN LANGUAGE TEACHING
}

\author{
Albert Weideman \\ University of Pretoria
}

As in many other countries, communicative language teaching (CLT) became the orthodoxy in second language teaching in many sub-Saharan African education systems in the last two decades of the previous century. There is enough evidence, however, to indicate that it has not been adopted by a critical mass of language teachers in their day-to-day classroom practice, as distinct from their professed adherence to its main tenets. There may be many reasons for this resistance. Markee's (1993) discussion of these indeed picks up a number of points that may be worth following up. This paper looks at three instructional tools that may assist teachers in overcoming resistance and adopting a communicative approach. The first is an instrument developed by Shaalukeni (2000) for use in her own work as an advisory teacher in northern Namibia. The paper discusses the employment of this instrument in her action research study into stimulating the use of pair work tasks in English second language classes. The second and third instruments help teachers to articulate their beliefs about language learning, as well as to examine whether these beliefs are in harmony with what we know about language learning, and aligned with what the teachers themselves profess. Such strategies are not sufficient to bring about change, but they may be the beginning of overcoming resistance to what is new.

Gedurende die laaste twee dekades van die twintigste eeu het kommunikatiewe taalonderrig, soos elders ook die geval is, tweedetaalonderrig in talle onderwyssisteme van Afrika-lande suid van die Sahara oorheers. Daar is egter meer as genoeg bewyse dat 'n kritieke massa onderwysers hierdie aanpak nog nie in hul daaglikse onderwyspraktyk geïmplimenteer het nie, alhoewel hierdie onderwysers tog te kenne gee dat hulle die aanpak oor die algemeen professioneel aanvaarbaar vind. Daar kan seker vele redes aangevoer word vir hierdie weerstand. Markee (1993) se uiteensetting van moontlike redes bevat talle punte wat die moeite werd is om oor na te dink. Hierdie artikel kyk na drie instrumente wat 'n mens sou kon gebruik om onderwysers te help om weerstand teen 'n kommunikatiewe aanpak te bowe te kom. Die eerste van die drie is deur Shaalukeni (2000) ontwikkel, vir gebruik in haar eie werk as vakadviseur in die noorde van Namibië. Die aanwending van hierdie instrument in haar aksienavorsing-ondersoek, wat daarop gemik was om leerders in Engels as tweedetaalklasse in pare te laat werk, word bespreek. Die tweede en derde instrumente wat ter sprake is, maak dit vir onderwysers moontlik om hul oortuigings oor die aanleer van taal te verwoord, asook om hulleself af te vra in watter mate hierdie oortuigings met ons kennis oor taalonderrig ooreenstem. Hierdie strategieë is weliswaar nie voldoende om verandering te waarborg nie, maar kan tog die begin wees van 'n poging om weerstand teen nuwe taalonderrigmetodes te bowe te kom. 


\section{A MISMATCH OF PROFESSED BELIEFS AND PRACTICE}

As in many other countries, communicative language teaching (CLT) became the orthodoxy in second language teaching in many sub-Saharan countries in the last two decades of the twentieth century. In the reconstruction of education and education systems that occurred in this period, the adoption of learner-centred approaches was common. In the field of language teaching, there is no doubt that CLT belongs to these kinds of approaches. The domination of CLT is, however, not unique to Africa: it had indeed in that same period spread to most parts of the English language teaching world, and one would find very few teachers who would actively voice opposition to its underlying rationale or instructional philosophy.

This notwithstanding, there is mounting evidence that in a number of instances and localities CLT has not been adopted by a critical mass of language teachers (cf. Shaalukeni 2000 and Tesfamariam 2000 for two well-documented case studies of the problems experienced in implementing CLT in, respectively, Namibia and Eritrea; for further and related discussion, cf. too Shaalukeni \& Weideman 2000, Van Rensburg \& Weideman 2002, Habte 2001 and Estifanos 2001). This article will, in the first instance, deal specifically with the documented examples in Namibia and Eritrea, and will make no claims about South Africa. That some of the discussion may relate to the latter context goes without saying, but the data presented refers in the first instance to these two countries. The limited focus on Namibia and Eritrea thus involves, in an article of this nature, less attention to the situation in South Africa, and the paper should therefore not be read as a survey of CLT in South Africa. Such a focus may be motivated, in my opinion, by us at present knowing less about language teaching conditions elsewhere in Africa than may be warranted; since more and more students from these countries are finding their way into post-graduate language teaching programmes of teacher education institutions, one hopes that descriptions of the context of language teaching in such countries may be informative or illuminate aspects that are of direct concern to South African teacher educators. The findings for Eritrea and Namibia confirm that, quite often, in their day-to-day classroom practice, teachers continue to employ styles that are opposed to the spirit and practice of CLT, to which they would profess their adherence. Often, teachers would not be able to articulate the main characteristics of CLT beyond a few commonplaces such as its 'learner-centred' approach, or that, through CLT, they have found a new commitment to 'oral' work - indeed the phenomenon of 'oral' work as a fetish is one of the key misinterpretations of CLT:

... the interpretation that many teachers have of CLT, that it emphasises only the spoken form of the language, is ... often related to teachers' own professional histories: when one has struggled to teach 'oral' as required by the Direct method, the great variety of speaking tasks encountered in CLT is like a gift from above. One then thinks of CLT tasks as just another addition to the 'oral' or conversation practice of one's essentially Direct method style of teaching (Weideman 2002a: 42).

What is noteworthy, however, is that this mismatch between professed belief about language teaching and learning, and the actual styles of language instruction employed by teachers, is not unique to these countries on the African continent. Indeed, in studies done elsewhere, the findings remain much the same. The study done by Karavas-Doukas (1996) among Greekspeaking teachers of English in Greece, for example, show just how big the differences are between these teachers' practices and their beliefs. 
This brings us to the second focus of this article, which is the question whether, if there is a mismatch between instructional practice and belief, this rift can be healed. The introduction especially the unsuccessful introduction - of CLT can, when one considers it from the angle of achieving an alignment between belief and practice, be viewed as a case of the introduction of an innovation, and therefore potentially susceptible to the explanations offered in the literature for successful or unsuccessful language teaching innovations (cf. Markee 1993). Using CLT as such a case study, I shall nonetheless present the potential remedies discussed below as neither exhaustive (i.e. involving a case for a comprehensive re-appraisal of CLT), nor as limited to CLT. Indeed, they may well apply to the introduction of any innovation in language teaching, and to 'good language teaching' (whatever that might be) in general.

A third point relating to the scope and argument of this article is pertinent here. There may be many explanations for teachers' reluctance to embrace an innovation like CLT. The first, and probably the one that is most frequently offered, is that teachers are ignorant. If for a moment one disregards the offensiveness of such a suggestion, in all of the contexts referred to in this article, viz. Greece (cf. Karavas-Doukas 1996), Namibia (cf. Shaalukeni 2000, Damens 2001) and Eritrea (Tesfamariam 2000, Habte 2001, Estifanos 2001), it is clear not only that teachers received frequent in-service training and had adequate support, but also that teachers were often able to offer sophisticated (normally behaviourist) explanations both of their own beliefs and of the main tenets of CLT. Two examples may make this point even clearer. In Tesfamariam's work (2000), the conclusion is reached that, in spite of having received training, and in spite of having everything at hand in the form of a CLT textbook, teachers still managed to avoid, with some ingenuity, the CLT tasks that the textbook prescribed. In Shaalukeni's (2000) case the reluctance is even more evident. She is both a teacher educator and subject advisor in the region, and a good half of the data that she gathered came from schools where she had, in fact, done what she normally did, which was to tell teachers that she would like to see a lesson involving group work, and offer to assist them. It is, of course, possible for group work to be teacher-centred, but the idea here was to assist teachers to introduce an information gap activity to be done in pairs - a technique that lies at the heart of CLT. Although she helped the teacher to plan for each of the remaining four lessons to be observed, nothing came of the these plans:

... teachers were unable to adapt even slightly towards accommodating a learner-centred approach, in spite of suggestions, advice, planning, and agreements made beforehand in this regard (2000: 83).

What could be the reason for this? At the first school, the teacher insisted that 'the learners did not like to work together in groups' (Shaalukeni 2000: 43) (which is, of course, possible). At a second school, the teacher insisted, after a single attempt at a pair work activity, that the lack of proficiency in English among learners meant that she had to focus more strongly on grammar (Shaalukeni 2000: 49). Her response to what was perhaps a situation in which learners did not have 'enough' language for the particular task set was that in the next lesson, 'there was 'no learner-learner interaction, and learners' responses are often single word answers in the mother tongue' (Shaalukeni 2000: 49f.).

These examples should make clear why one must perhaps look elsewhere for an explanation for what appears to be a fairly widespread phenomenon. Finding such an explanation for teachers' avoidance of CLT not in their ignorance, but in a mismatch of their beliefs and practices, is, in this article, considered as a plausible hypothesis. 


\section{CHARACTERISTICS OF CONVENTIONALITY IN LANGUAGE TEACHING}

In a context where teachers profess to have one set of beliefs, yet practise another, a number of characteristics usually define language teaching classes. For one thing, in a context where the traditional and the conventional prevail in language teaching, the policies that introduce and prescribe the implementation of CLT in sub-Saharan Africa are often adopted as part of a national overhaul of the entire pre-independence education system. These changes are introduced and backed by the new education authorities, are therefore frequently promoted through in-service language teacher training projects, and the latter in turn are often supported by donor funding or expertise (cf. Damens 2001). Either the new policy prescribed takes 'learner-centredness' as a central tenet, as in Namibia (see Shaalukeni 2000), or it postulates a new, communicative approach to the teaching of language (as in Eritrea; cf. Tesfamariam 2000), or both, usually and quite often in combination. Often, too, as we have noted above, the introduction of a communicative approach is immediately misunderstood by the first-line implementers as a kind of hyped-up Direct Method, which requires lots of 'oral communication'.

In addition to such a general adoption of 'learner-centredness', the new policies require from teachers to implement approaches that conflict with traditional methodologies, are antiauthoritarian, and require more participation on the part of learners than is customary or possible in any conventional approach. The current South African experiment with outcomesbased education, for example, is justified most frequently with reference to its replacement of traditional classroom practices with instrumental, facilitative, results-oriented goals.

Tesfamariam (2000: 111) identifies some of the specific classroom practices that obtain in Eritrea. The classrooms in his study are characterised by the lecture-mode, mostly for the sake of explaining some point of grammar, as well as by students copying down notes from the blackboard, by the use of the mother tongue to explain the meaning of English words, and by students sitting silently, and speaking only when asked by the teacher to answer questions. The conventional nature of these classroom practices is evident. His findings are confirmed by those of Estifanos (2001), who recently investigated the vocabulary teaching and learning practices of Grade 9 English teachers in the same country. He observes (Estifanos 2001: 114) that often in vocabulary teaching

... the teachers did most of the explanation themselves. The students, in turn, had to listen and copy down what they have heard into their exercise books. Of course, this keeps them passive, and prevents them from trying things out themselves ... In traditional teaching practice, which is the practice usually encountered in the Eritrean classrooms, the teacher is expected to do more of the talking, and the students to do the listening.

Similarly, in the study that concerns the classroom practices that obtain in a number of localities in northern Namibia, Shaalukeni (2000: 85) has found what she terms the typical 'quiet African classroom.' Her experience is confirmed by recent UNICEF studies that she refers to, which indicate that

teachers and parents in African countries have a picture in their minds of a classroom as a place where silence and strict discipline should prevail. This is the kind of classroom our teachers carry around in their minds, the one in which they wish to teach. (Learners) are not 
accustomed to talk to one another other than when conventionally responding to the teacher's questions.

These, then, are the general and specific characteristics of the instructional contexts into which CLT is introduced, often unsuccessfully. As Shaalukeni has pointed out, in general

... the picture is one in which traditional styles of instruction remain firmly entrenched, and the innovations associated with a learner-centred approach are resisted (Shaalukeni 2000: 87).

\section{RESISTANCE TO CLT}

For any innovation to become an effective and efficient alternative to established practice, certain conditions need to be fostered. Factors that militate against establishing these desired conditions are :

- Conflicts between language teaching practice on the one hand, and general education and language curriculum policy on the other hand.

- The prevalence and perpetuation of traditional styles of teaching, despite the introduction of anti-authoritarian, learner-centred, collaborative and interactive methodologies.

If Markee's (1993) distinctions between the various kinds and phases of adopting an innovation are correct, then it appears that the teachers in the studies which are the focus of this article have not adopted CLT.. Markee (1993: 235) distinguishes between innovators (who accept the innovation first) followed by early adopters, who together make up the first $25 \%$ of those who eventually take up the innovation. These are followed by those who constitute the 'early majority,' and 'late majority,' and, finally, the 'laggards' and 'resisters'. There is no evidence, at least in the contexts that are being referred to here, of innovators and early adopters implementing CLT, and no indication of any majority of teachers, whether early or late, falling in with them. There are, instead, indications of a majority of resistant teachers. One must conclude that, in the contexts surveyed in the studies cited here, there has not yet been a shift to a communicative and learner-centred approach to language teaching within classrooms. Ways must be found to encourage teachers to adopt innovation such as CLT. [One can effect change - as you suggest later in the article]

\section{TEACHERS' OBJECTIONS}

What reasons do teachers give for not adopting CLT? In the studies that were referred to above, teachers cited several reasons. We examine several in turn:

1) A lack of proficiency of learners in the target language (Shaalukeni 2000: 43) is most often cited by teachers as a reason why they cannot implement CLT. [You need to give the question(s) and the practical context in which it/they were posed. See following paragraph] 
In each of the five schools observed, Shaalukeni conducted interviews with teachers afterwards, specifically to determine why it was that they either did not attempt, or had abandoned (in spite of plans made together with the observer beforehand) any attempt at CLT type activities. As Shaalukeni (2000: 88f.) observes, the

... irony of this is, of course, that the very type of activities that could help learners achieve greater ease and fluency in the target language is the one that ... teachers are unable to handle with any amount of confidence at present. Instead, other factors are blamed, or different excuses are conceived. No-one would think of putting the blame for the learners' lack of proficiency on the currently dominant, conventional approach to teaching and learning English.

2) That using group or pair work (as required by many CLT techniques, such as role plays, discussion tasks, and information gap exercises) would be too time-consuming.

As Tesfamariam has noted, however, it often takes several times longer to do the traditional activity than to implement a CLT task. He gives the following example of a teacher who used the typical Direct Method task of having learners prepare and deliver 'speeches' on teacher-defined topics:

In the English class of T4 [the fourth teacher in the group surveyed] at S3 [the third school involved in the research], speaking activity was presented individually, in accordance with practices inherited from the Direct Method. Only 13 students [out of a class of 75] had the chance to present their speech in response to five questions written on the blackboard. According to the teacher, the activity had been planned to continue until all students had had a turn. This means that a single exercise will take a week or more. Within that period of time, every student will have a chance to speak English for only three minutes and for the remainder would have to sit as a listener until all the other students have presented their speech. Had the teacher applied pair or group work, however, the same activity would not have taken more than five minutes (Tesfamariam 2000: 91).

It is interesting to note, then, that even where the communicative techniques prescribed in the teacher's manual and textbook not only could have saved a lot of class time, but also would have provided each learner with ample opportunity to practise the language, teachers preferred to use an older, time-consuming and impractical method, all the while claiming, without as much as a hint of awareness of the contradiction, that CLT is actually the kind of language teaching that requires more time.

\section{3) That their classes are too large to implement CLT.}

Again, as Tesfamariam (2000: 100) has correctly noted, even though it is probably true that the degree of difficulty in presenting language tasks increases with an increase in class size,

... The communicative approach is, in fact, one of the few methodologies or approaches that make sense to use in large classes. Most teachers who complained about class size, however, did not use pair or group work activities at all (emphases in the original). 
More sophisticated objections offered by teachers might include:

\section{4) Learners will learn each other's mistakes.}

The research studies discussed by Lightbown and Spada (1993: 86) reveal that for the groups of learners investigated, learners did not make any more errors with their peers than with a person of advanced ability, or with a model speaker. They remark:

This is a particularly interesting finding because it calls into question the argument that learners need to be exposed to a ... model (i.e. the teacher) ... at all times if we are to ensure that they produce fewer errors (Lightbown \& Spada 1993: 86).

For a different view, see Porter (1986) and Yule and Donald (1990) quoted in Ellis (1994: 600).

If the teacher does not control every language utterance, bad language habits may form, which will be difficult to eliminate.

It is now accepted that not all learners are at the same stage of development, but may be at an intermediate stage in their language production, where certain errors may normally occur, sometimes even systematically. These are corrected by learners themselves as their language ability develops, or, if teachers know accurately what the right moment is to focus learners' attention on the feature that has to be taught (cf. Lightbown \& Spada 1993: 94f., 96f.), then it can theoretically be taught. If, however, learners are prevented from producing language because they are afraid of being evaluated negatively by the teacher, this may well retard their development. One must also remember that no conclusive case in favour of immediate error correction has yet been made (for a review, cf. Truscott 1996). An additional problem is that, in the classes to which Tesfamariam's study refers, many of the 'errors' corrected are not errors at all, as is evidenced by the following transcription of a stretch of classroom talk (T2 = second teacher observed, $\mathrm{S}=$ learner) (Tesfamariam 2000: 117):

T2: Why was the sea dangerous?

S: $\quad$ Because ....

T2: Do not start with 'because.' Sit down!

If teachers' knowledge of English grammar is suspect (see below), and if they do not know how to identify 'the right moment to create increased awareness on the part of the learner' (Lightbown \& Spada 1993: 97), it is unlikely that the 'errors' that are corrected will indeed be errors, or, if they are, that they may ever be eliminated by creating an awareness of them.

5) CLT classes are too noisy. Colleagues may complain; the principal may think that there is chaos in one's class.

CLT classes indeed produce more sound than conventional language classes, but, as most experienced practitioners will be able to testify, after an initial period of heightened and more animated activity, the noise in the class settles down to a purposeful hum. Such 
noise is the very opposite of the kind of noise in a class of learners who are shrieking and audibly going out of control.

6) Learners need to be informed of the basic facts of English grammar, of which they have no knowledge.

The trouble is that teachers' own knowledge of English grammar is often not very sound. Shaalukeni (2000: 55) gives the following example of a teacher's attempts at teaching learners the 'future tense':

Teacher: Read your sentences you chose yesterday.

Learner A: He said, 'I'll kill the lot of them.' Present tense.

Teacher: Are we all agree that it is present tense? What tense is that sentence? Who can help us?

Learner B: Future tense.

Teacher: What is telling us that this future tense. What word tells us that the sentence is in future tense? This is future tense because we speak of will.

Rationally, there seems to be very little explanation for the stock responses that teachers give for not attempting CLT. To be sure, there are also several stock explanations from education department officials or from teacher trainers for the lack of implementation of CLT, all of which sound plausible, but are problematic once one examines them. One of the common explanations is that teachers may merely be ignorant, not resistant. Ignorance is, of course a first cousin to resistance: we resist the things that threaten our security] Yet, as we have noted above, there is no evidence in the studies referred to in this article that this is the case. The other is that they need (more) training. If, in the contexts of the studies referred to here, they do, then the training will have to be wholly different from the training they have already received. It is interesting, however, that one knows of no single study that has conclusively proved - not merely claimed, but demonstrated - that teachers' ignorance or lack of training may be to blame. The real reasons therefore seem to be eluding us, though, as has been argued elsewhere (Weideman 2002b), we may need to explore teachers' adherence to (mainly conventional) beliefs about language learning and teaching (cf. too Karavas-Doukas 1996) to find a coherent set of reasons.

\section{OVERCOMING THE RESISTANCE}

Whatever the source of this resistance is, it is nonetheless unlikely that we will go back to an authoritarian style of grammar teaching, or to the official encouragement of traditional language teaching practices. If that is the case, how can teachers be assisted to overcome their resistance to CLT, or for that matter, to any alternative, innovative or potentially more effective style of language teaching that might succeed CLT? Below, we examine three ways of doing so. All make use of a rational strategy, i.e. allow teachers themselves to realise that their practice may be at variance with what they profess, and to articulate (and, if necessary, subsequently challenge) their own beliefs about learning and teaching English as an additional language. They are not presented here either as promoting a comprehensive awareness of CLT, nor as sufficient - in fact rational strategies can probably never be so. The instruments are also not presented as strategies that have already been proved to be effective. They do, however, constitute a possible starting point for renewal and change. 
The first way derives from Shaalukeni's (2000) attempt to gauge, through a participant observation process, the possibilities of implementing especially pair work activities in classes where English is being taught as an additional language (cf. too Habte 2001 for a recent survey of information gap tasks, their benefits, design and use in a scarce resource environment).

Shaalukeni designed her observation instrument around seven parameters, on which she and the teacher being observed could rate the extent to which each contributed (or detracted from) the goal of implementing group or pair work. The measures (for a summary, see Shaalukeni \& Weideman 2000: 1) are:

1. The nature of teacher talk

2. The nature of learner talk

3. The planned use of group or pair work in the lesson to ensure meaningful learner participation

4. Time spent on learner activities, including group or pair work

5. The extent to which the target language, English, is used in group or pair work

6. The extent to which the mother tongue is used in group or pair work

7. The extent of change discernible in teaching practice (where applicable)

Shaalukeni surveyed the language instruction practices of Grade 7 teachers at five schools (2000: 20). Each of the five teachers involved was observed five times, i.e. during five different lessons (hence the seventh measure, above, concerning the extent of change).

Here is the complete instrument:

\section{CLASSROOM OBSERVATION CHECKLIST}

School:

Topic:

Grade:

Date:

Circle the most appropriate numbers:

\section{Nature of teacher talk}

\begin{tabular}{|l|l|l|l|l|}
\hline \multicolumn{1}{|c|}{1} & \multicolumn{1}{|c|}{2} & \multicolumn{1}{c|}{3} & \multicolumn{1}{c|}{4} & \multicolumn{1}{c|}{5} \\
\hline $\begin{array}{l}\text { talks far too little to } \\
\text { allow group work to } \\
\text { progress } \\
\text { meaningfully }\end{array}$ & $\begin{array}{l}\text { could certainly use } \\
\text { more talk to making } \\
\text { group work function } \\
\text { effectively }\end{array}$ & $\begin{array}{l}\text { talks just about the } \\
\text { right amount to allow } \\
\text { group work to } \\
\text { progress } \\
\text { meaningfully }\end{array}$ & $\begin{array}{l}\text { must talk less if } \\
\text { group work is to } \\
\text { progress more } \\
\text { meaningfully }\end{array}$ & $\begin{array}{l}\text { talks so much that } \\
\text { group work becomes } \\
\text { virtually impossible }\end{array}$ \\
\hline
\end{tabular}

\section{Nature of learner talk}

\begin{tabular}{|l|l|l|l|l|}
\hline \multicolumn{1}{|c|}{1} & \multicolumn{1}{|c|}{2} & \multicolumn{1}{c|}{3} & \multicolumn{1}{c|}{4} & \multicolumn{1}{c|}{5} \\
\hline $\begin{array}{l}\text { lesson has far too } \\
\text { little learner talk to } \\
\text { indicate meaningful } \\
\text { participation }\end{array}$ & $\begin{array}{l}\text { some talk, but } \\
\text { learners could } \\
\text { certainly talk more to } \\
\text { ensure meaningful } \\
\text { participation }\end{array}$ & $\begin{array}{l}\text { learner talk just about } \\
\text { the right amount to } \\
\text { ensure meaningful } \\
\text { participation }\end{array}$ & $\begin{array}{l}\text { learner talk so much } \\
\text { as to begin to disrupt } \\
\text { discipline and } \\
\text { learning }\end{array}$ & $\begin{array}{l}\text { learner talk } \\
\text { excessive, disrupting } \\
\text { a disciplined learning } \\
\text { environment }\end{array}$ \\
\hline
\end{tabular}


3. Planned use of group or pair work in the lesson to ensure meaningful learner participation

\begin{tabular}{|c|c|c|c|c|}
\hline 1 & 2 & 3 & 4 & 5 \\
\hline $\begin{array}{l}\text { very little learner } \\
\text { activity, group or pair } \\
\text { work planned to } \\
\text { allow for meaningful } \\
\text { participation }\end{array}$ & $\begin{array}{l}\text { planned group and / } \\
\text { or pair work, but too } \\
\text { little to allow for } \\
\text { meaningful learner } \\
\text { participation }\end{array}$ & $\begin{array}{l}\text { just about the right } \\
\text { balance of group } \\
\text { work and other } \\
\text { activities to allow for } \\
\text { meaningful } \\
\text { participation }\end{array}$ & $\begin{array}{l}\text { planned use provides } \\
\text { evidence of over-use } \\
\text { of group work as a } \\
\text { learner participation } \\
\text { technique }\end{array}$ & $\begin{array}{l}\text { group work used so } \\
\text { excessively as to } \\
\text { prevent meaningful } \\
\text { learning to take place }\end{array}$ \\
\hline
\end{tabular}

4. Time spent on learner activities, including group or pair work

\begin{tabular}{|l|l|l|l|l|}
\hline \multicolumn{1}{|c|}{1} & \multicolumn{1}{|c|}{2} & \multicolumn{1}{|c|}{3} & \multicolumn{1}{c|}{4} & \multicolumn{1}{c|}{5} \\
\hline $\begin{array}{l}\text { too little to allow for } \\
\text { meaningful learner } \\
\text { participation }\end{array}$ & $\begin{array}{l}\text { though some time is } \\
\text { devoted to it, not } \\
\text { nearly enough }\end{array}$ & $\begin{array}{l}\text { just about the right } \\
\text { amount to allow } \\
\text { meaningful } \\
\text { participation }\end{array}$ & $\begin{array}{l}\text { so much that it could } \\
\text { even be reduced in } \\
\text { order to consolidate } \\
\text { learning }\end{array}$ & $\begin{array}{l}\text { undoubtedly so much } \\
\text { as to be disruptive of } \\
\text { meaningful learning }\end{array}$ \\
\hline
\end{tabular}

\section{Extent to which the target language, English, is used in group or pair work}

\begin{tabular}{|l|l|l|l|l|}
\hline \multicolumn{1}{|c|}{1} & \multicolumn{1}{|c|}{2} & \multicolumn{1}{c|}{3} & \multicolumn{1}{c|}{4} \\
\hline $\begin{array}{l}\text { too little to allow for } \\
\text { meaningful learner } \\
\text { participation }\end{array}$ & $\begin{array}{l}\text { some use of the } \\
\text { target language, but } \\
\text { certainly not enough }\end{array}$ & $\begin{array}{l}\text { a good measure of } \\
\text { the target language is } \\
\text { used }\end{array}$ & $\begin{array}{l}\text { a larger than } \\
\text { expected use of the } \\
\text { target language is } \\
\text { evident }\end{array}$ & $\begin{array}{l}\text { use of the target } \\
\text { language than } \\
\text { expected }\end{array}$ \\
\hline
\end{tabular}

6. Extent to which the mother tongue is used in group or pair work

\begin{tabular}{|l|l|l|l|l|}
\hline \multicolumn{1}{|c|}{1} & \multicolumn{1}{|c|}{2} & \multicolumn{1}{c|}{3} & \multicolumn{1}{c|}{4} & \multicolumn{1}{c|}{5} \\
\hline $\begin{array}{l}\text { very little use of the } \\
\text { mother tongue } \\
\text { evident; sufficient } \\
\text { opportunities for } \\
\text { using target language }\end{array}$ & $\begin{array}{l}\text { some use of the } \\
\text { mother tongue, but } \\
\text { not so much as to } \\
\text { prevent use of the } \\
\text { target language }\end{array}$ & $\begin{array}{l}\text { a mix of the mother } \\
\text { tongue and the target } \\
\text { language, hindering } \\
\text { opportunities for the } \\
\text { use of the target } \\
\text { language }\end{array}$ & $\begin{array}{l}\text { so much use of the } \\
\text { mother tongue that } \\
\text { there are very few } \\
\text { opportunities for the } \\
\text { use of the target } \\
\text { language }\end{array}$ & $\begin{array}{l}\text { mother tongue is } \\
\text { used to the virtual } \\
\text { exclusion of the } \\
\text { target language }\end{array}$ \\
\hline
\end{tabular}

7. Extent of change discernible in teaching practice (where applicable)

\begin{tabular}{|l|l|l|l|l|}
\hline \multicolumn{1}{|c|}{1} & \multicolumn{1}{|c|}{2} & \multicolumn{1}{c|}{3} & \multicolumn{1}{c|}{4} & \multicolumn{1}{c|}{5} \\
\hline $\begin{array}{l}\text { no evidence of } \\
\text { change in teacher's } \\
\text { classroom practices } \\
\text { at all; traditional } \\
\text { teaching style } \\
\text { prevails }\end{array}$ & $\begin{array}{l}\text { some change evident, } \\
\text { but too little to } \\
\text { indicate that a new } \\
\text { style has been, or is } \\
\text { in the process of } \\
\text { being adopted }\end{array}$ & $\begin{array}{l}\text { a fair amount of } \\
\text { change is evident, } \\
\text { indicating that the } \\
\text { teacher may possibly } \\
\text { adopt a new style }\end{array}$ & $\begin{array}{l}\text { a good amount of } \\
\text { change is evident, } \\
\text { indicating that the } \\
\text { teacher has already } \\
\text { chosen to adopt a } \\
\text { new style }\end{array}$ & $\begin{array}{l}\text { an unexpectedly } \\
\text { large amount of } \\
\text { change, indicating an } \\
\text { enthusiastic adoption } \\
\text { of a new style }\end{array}$ \\
\hline
\end{tabular}

The instrument is relatively uncomplicated, and yielded results that prompted further discussion and probing.

If teachers create opportunities for learning through active participation in group work, and learners take up these opportunities, one may say that there is meaningful participation in the classroom. In the classroom observation checklist, I have used the concept meaningful participation as a subjective measure of the extent to which the teacher is able to organise and structure learner-to-learner and learner-to-teacher participation or interaction with a view to making learning possible in the classroom (Shaalukeni 2000: 22f.).

The other benefit of using such an instrument to promote discussion and debate about teaching practice is that it gives an intelligible meta-language for teacher and observer to use 
in the discussion. No doubt the teacher and the observer may differ, as in the pilot study undertaken here by Shaalukeni, as to the ratings, but at least it creates an opportunity for teachers to view their teaching practice through the eyes of others, and to begin reflecting on their practice. A critical component of the classroom interaction being reviewed by observer and teacher in this instance concerns the nature of classroom talk. Reflecting on the absence or presence of opportunities for talk on the part of learners, and on the relation of these to the teacher's conventional domination of such opportunity, is pivotal in considering whether the implementation of CLT is possible. The observation instrument provides the basis for such reflection.

An additional advantage of using Shaalukeni's observation schedule is that the meta-language that is employed in the instrument is relatively free from jargon, which makes it intelligible and likely to be more widely used.

The second way of overcoming resistance to the innovation that CLT constitutes within a fairly traditional instructional context derives from a seminar on changing one's beliefs about language learning and teaching that I conducted at the beginning of the year. To start the discussion, I used two questionnaires. The first was in the form of a series of statements that participants were asked to mark as True or False, before and after reading the preliminary material for the workshop. Here are the instructions to participants, as well as the list of statements:

Before you begin this reading, mark as TRUE or FALSE the set of statements below. After you have read it, mark your post-reading opinion too. Please bring along this report to the seminar; it will form the basis of the discussion in the first session.

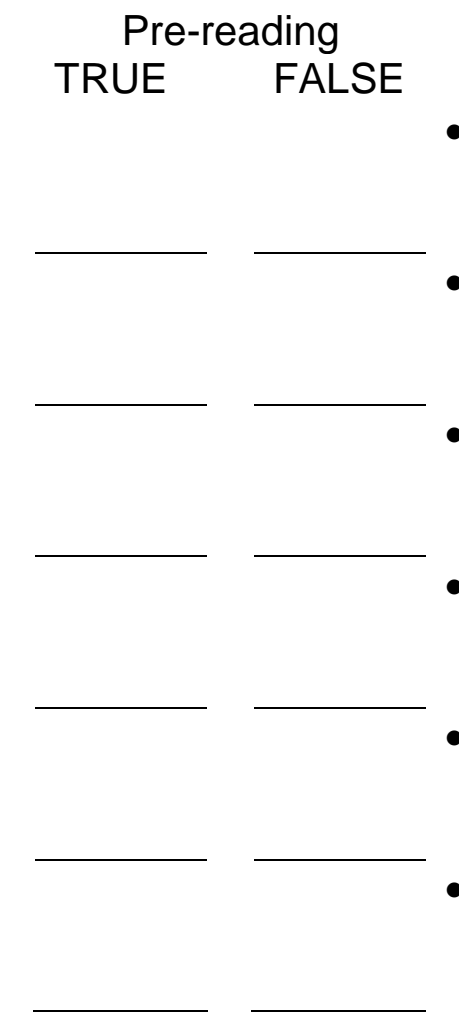

Pre-reading TRUE FALSE

- The beliefs that support our teaching of language may be adopted quite unconsciously.

- In the 1980s, fluency became more prominent as a goal of language teaching than accuracy.

- Before this, teachers believed that errors had to be corrected immediately.

- There is probably no better teaching technique than to require learners to repeat.

- Many teachers would feel it is a compliment if their teaching is described as 'eclectic'.

- Studies have shown divergences between what teachers profess and how they actually teach.
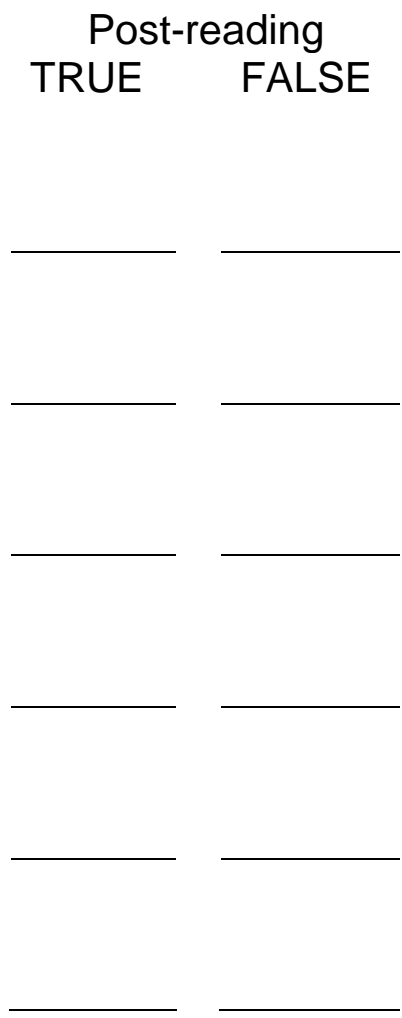
Did you change any of your opinions about the truth of falsity of these statements after reading the text? Why?

The text being referred to here as preliminary reading was the introductory chapter to Weideman's (2002a) Designing language teaching - on becoming a reflective professional, which deals with the issue of the commitments we make when we teach language.

The second questionnaire was adapted from Lightbown \& Spada's (1993: $x v$ ) initial one. It is probably by now well-known in the language teaching profession, but I was prompted, in the context of a language instruction organisation that needed discussion and rational debate about language teaching practices, to make use of it again, and I record it here because it turned out to be a very good starting point for a reconsideration of one's language teaching practice in that environment. Here is the adaptation that I used to engender debate and discussion among language instructors. The original list has been reduced from 12 to 8 questions, and for each statement, the participants were required to mark, on a seven-point scale, the extent of their agreement or disagreement:

\section{What do I believe about language learning?}

1. Parents usually correct young children when they make grammatical errors.

2. People with high IQs are good language learners.

3. To learn another language successfully in a classroom, the most important factor is motivation.

4. Teachers should present grammatical rules one at a time, and learners should practice examples of each one before going on to another.

5. Learners' errors should be corrected as soon as they are made in order to prevent the formation of bad habits.

6. Teachers should use materials that expose students only to those language structures that they have already been taught.

7. When students are allowed to interact freely (for example in group or in pair activities), they learn each other's mistakes.

8. Students learn what they are taught.

Adapted from P.M. Lightbown \& N. Spada (1993: xv).

Together, these two sets of statements allowed the language teachers present to begin to articulate their own views on language learning and teaching. On this particular occasion, the rest of the day was spent considering topics such as good language learner profiles (Wenden 1991: 121), learners' ways of language learning (Nunan 2000; Lepota \& Weideman 2002), including a consideration of the instructors' own experiences of learning an additional language, the role of grammar in teaching an additional language (cf. Truscott 1996), and what role correction and being corrected by the teacher plays in learning a new language. 
These are rational change strategies, since they are designed to expose language teachers gradually to a consideration of new ways and methods of teaching, especially ways that may be more closely aligned with findings in the literature. They are not sufficient to bring about change, however. As Shaalukeni (2000: 90) has remarked, such change has (in part) to be accompanied by 'a willingness from within.' Articulating one's own position in terms of the current possibilities in the field of language teaching is nonetheless a powerful stimulus to make a start at changing those beliefs that prevent one from using innovations in one's teaching. Having articulated one's own beliefs about language learning and teaching, and having been confronted with the results of an observation of one's own practice, one is also able to detect the contradictions that exist between what one professes and what one practises. At least, this articulation is a beginning, and, when supplemented with other resources that make change easier, such as the availability of up-to-date materials, institutional acceptance of the necessity for change, and the political will or policy prescription (cf. Markee 1993: 234 et passim) to change one's style of language teaching, there is a better chance that language teachers may embrace new ways of teaching that are in tune not only with their own beliefs, but also with their learners' styles of learning.

\section{REFERENCES}

DAMENS, P. 2001. Second language programme evaluation in Namibia: toward identifying criteria. Unpublished master's mini-thesis, University of the Western Cape Bellville.

ELLIS, R. 1994. The study of second language acquisition. Oxford: Oxford University Press.

ESTIFANOS, S. 2001. An investigation of vocabulary teaching and learning in Eritrean Grade 9 classes. Unpublished master's mini-thesis, University of the Western Cape Bellville.

HABTE, A. 2001. The development of supplementary materials for English language teaching in a scarce resource environment: an action research study. Unpublished master's mini-thesis, University of the Western Cape Bellville.

KARAVAS-DOUKAS, EK. 1996. Using attitude scales to investigate teachers' attitudes to the communicative approach. ELT Journal,50 (3): 187-198.

LEPOTA, B. \& A.WEIDEMAN. 2002. Our ways of learning language. SAALT Journal for Language Teaching, 36(3\&4): 206-219.

LIGHTBOWN, PM AND N SPADA. 1993. How languages are learned. Oxford: Oxford University Press.

MARKEE, N. 1993. The diffusion of innovation in language teaching. Annual review of applied linguistics, 13: 229-243. 
NUNAN, D. 2000. Seven hypotheses about language teaching and learning. TESOL Matters, 10 (2): 1-9.

SHAALUKENI, L. 2000. Learner-centredness and group work in second language teaching: a shattered dream. The case of five primary schools in the Ondangwa West region, Namibia. Unpublished master's mini-thesis, University of the Western Cape Bellville.

SHAALUKENI, L AND A WEIDEMAN. 2000. Learner-centredness and group work in second language teaching: A shattered dream. The case of five primary schools in the Ondangwa West region of Namibia. Paper read at SACHES conference, Windhoek, Namibia. 16-18 October.

TESFAMARIAM, H. 2000. The alignment of the Grade 8 English syllabus in Eritrea with its implementation in the classroom. Unpublished master's mini-thesis, University of the Western Cape Bellville.

TRUSCOTT, J. 1996. Review article: The case against grammar correction in L2 writing classes. Language Learning, 46 (2): 327-369.

VAN RENSBURG, C AND A WEIDEMAN. 2002. Language proficiency: current strategies, future remedies. SAALT Journal for Language Teaching, 36 (1 \& 2): 152-164.

WEIDEMAN, AJ. 2002a. Designing language teaching: on becoming a reflective professional. Pretoria: BE at UP.

2002b. Resistance to change in language teaching: some African case studies. Paper read at the SAALA/LSSA 2002 conference. July.

WENDEN, A. 1991. Learner strategies for learner autonomy: planning and implementing learner training for language learners. New York: Prentice Hall.

\section{Biographic Note}

Professor Albert Weideman is the deputy director of the Unit for Unit for Language Skills Development at the University of Pretoria (Tel: 012-420 4957; email ajweideman@postino.up.ac.za) 